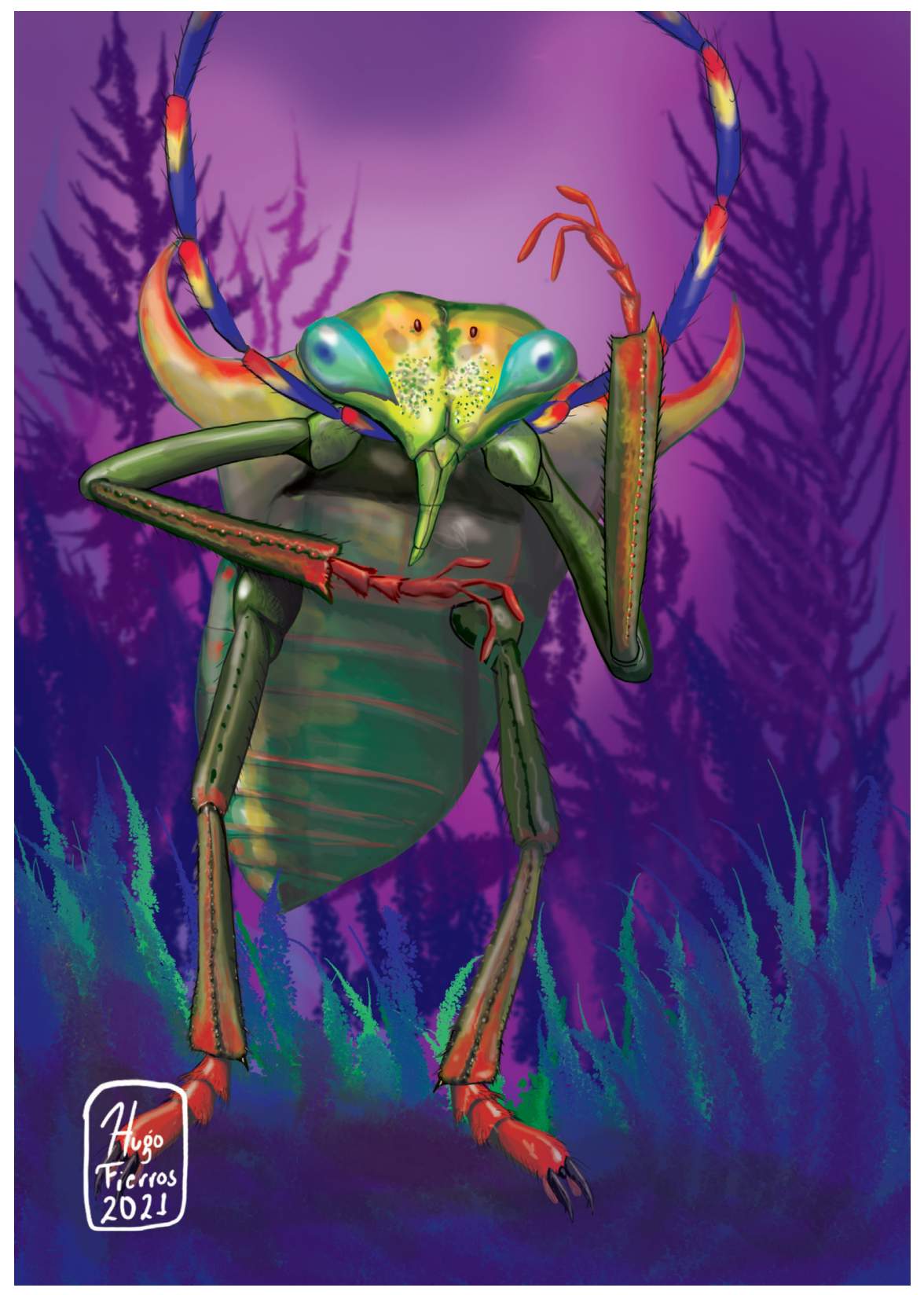

Dugesiana, Año 29, No. 1, (enero-junio, primer semestre 2022), es una publicación semestral, editada por la Universidad de Guadalajara, a través del Centro de Estudios en Zoología, por el Centro Universitario de Ciencias Biológicas y Agropecuarias. Camino Ramón Padilla Sánchez \# 2100, Nextipac, Zapopan, Jalisco, Tel. 37771150 ext. 33218, http://148.202.248.171/dugesiana/index.php/DUG/index, glenusmx@gmail.com. Editor responsable: José Luis Navarrete-Heredia. Reserva de Derechos al Uso Exclusivo 04-2009-062310115100-203, ISSN: 20079133, otorgados por el Instituto Nacional del Derecho de Autor. Responsable de la última actualización de este número: José Luis Navarrete-Heredia, Editor y Ana Laura González-Hernández, Asistente Editorial. Fecha de la última modificación 1 de enero de 2022, con un tiraje de un ejemplar.

Las opiniones expresadas por los autores no necesariamente reflejan la postura del editor de la publicación.

Queda estrictamente prohibida la reproducción total o parcial de los contenidos e imágenes de la publicación sin previa autorización de la Universidad de Guadalajara. 


\title{
Artículo
}

\section{Andricus partali n. sp. from Costa Rica (Hymenoptera: Cynipidae: Cynipini)}

\section{Andricus partali n. sp. de Costa Rica (Hymenoptera: Cynipidae: Cynipini)}

\author{
Juli Pujade-Villar *, Victor Cuesta-Porta* and Paul Hanson ** \\ "Universitat de Barcelona, Facultat de Biologia, Departament de Biologia Animal, Avda. Diagonal 645, \\ 08028-Barcelona (Spain).E-mail: jpujade@ub.edu; victorcp93@gmail.com; **Museo de Zoología, \\ Universidad de Costa Rica,, San Pedro, Costa Rica. e-mail: paul.hanson@ucr.ac.cr. \\ Corresponding author: Victor Cuesta-Porta. A/e: victorcp93@gmail.com
}

\section{RESUMEN}

Una nueva especie de avispa agalladora, Andricus partali n. sp. (Hym., Cynipidae, Cynipini), es descrita de Costa Rica induciendo agallas en hojas de Quercus costaricensis Liebm. (Sección Lobatae). Se proporciona la descripción, diagnosis e información sobre la distribución y biología de la nueva especie.

Palabras clave: avispas agalladoras, taxonomía, morfología, distribución, biología.

\section{ABSTRACT}

A new species of oak gallwasp, Andricus partali n. sp. (Hym., Cynipidae: Cynipini), is described from Costa Rica inducing galls on the leaves of $Q$. costaricensis Liebm. (Section Lobatae). We provide a description, diagnosis, and information about the distribution and biology of the new species.

Key words: Oak gallwasp, taxonomy, morphology, distribution, biology.

The oak gall wasps (Hymenoptera: Cynipidae: Cynipini) predominantly occur in the Holarctic region, but also in the Oriental and Neotropical. Historically, the Nearctic and Western Palaearctic regions have accumulated the greatest number of described species of oak gall wasps (Stone et al. 2002), but recently new hotspots of cynipid diversity are being discovered in the Eastern Palaearctic and Oriental regions (Pénzes et al. 2018). The Neotropics has been the most overlooked region with respect to the study of cynipids (Medianero and Nieves-Aldrey 2011a), but this is starting to change. During the last few years, this region has undergone a significant increase in sampling effort, mostly in Panama and, to a lesser extent, Colombia and Costa Rica. As a result, several species of in Neotropical oak gall wasp have been newly described belonging to the genera: Amphibolips Reinhard, Andricus Hartig, Bassettia Ashmead, Disholcaspis Dalla Torre Kieffer, Loxaulus Mayr, Melikaiella Pujade-Villar, Neuroterus Hartig, Odontocynips Kieffer and Striatoandricus Pujade-Villar, (e.g. CuestaPorta et al. 2020; Fernández-Garzón et al. 2017; Medianero and Nieves-Aldrey 2010, 2011a, 2011b, 2014; Medianero et al. 2011a, 2011b; Melika et al. 2009, 2011; Nieves-Aldrey and Medianero 2010; Nieves-Aldrey et al. 2021; PujadeVillar 2008; Pujade-Villar and Rodríguez 2015; PujadeVillar et al. 2015, 2017). New endemic genera have also been described: Barucynips Medianero and Nieves-Aldrey,
Coffeikokkos Pujade-Villar and Melika, and Zapatella Pujade-Villar and Melika (Medianero and Nieves-Aldrey 2013; Pujade-Villar et al. 2012a, 2012b, respectively).

The first cynipid species that was described for Costa Rica, was Odontocynips hansoni Pujade-Villar (Pujade-Villar 2008). Later descriptions include Andricus costaricensis, Pujade-Villar and Melika, 2009; Disholcaspis costaricensis Melika and Pujade-Villar, 2011; Coffeikokkos copeyensis Pujade-Villar and Melika, 2012; Neuroterus glandiphilus Nieves-Aldrey and Medianero, 2017 and $N$. titou Pujade-Villar and Hanson, 2021 (Melika et al. 2009; Melika et al. 2011; Pujade-Villar et al. 2012a; Medianero and Nieves-Aldrey 2017; Pujade-Villar and Hanson 2021, respectively). Currently, six species have been described from Costa Rica, though Pujade-Villar and Hanson (2006) estimated that the diversity of oak gall wasps (Cynipini) might be of more than 30 species. In this study, we describe a new species of Andricus, which represents the second record of this genus for Costa Rica.

\section{MATERIALS AND METHODS}

The examined material was collected in Costa Rica and sent to the University of Barcelona by the last author from galls collected on leaves of Quercus costaricensis Liebm.

Morphological terminology follows Liljeblad and Ronquist (1998), and Melika (2006), except for 
abbreviations of forewing venation, which follow Ronquist and Nordlander (1989). Cuticular surface terminology follows Harris (1979). Measurements and abbreviations used here include: F1-F12, 1st and subsequent flagellomeres; POL (post-ocellar distance) is the distance between the inner margins of the posterior ocelli; OOL (ocellar-ocular distance) is the distance from the outer edge of a posterior ocellus to the inner margin of the compound eye; LOL, the distance between lateral and frontal ocelli. The width of the forewing radial cell is measured from the margin of the wing to the Rs vein.

The SEM images were obtained using a field-emission gun environmental scanning electron microscope (FEI Quanta 200 ESEM) for high-resolution imaging without gold-coating the specimens. Gall images were taken with a Canon A1 camera with a $50 \mathrm{~mm}$ macro lens followed by Adobe Photoshop CS3 software processing. Adult images were taken with an Olympus SC30 camera, coupled to an Olympus U-CMAD3, adapted to an Olympus SZX10 stereomicroscope. Image stacking and processing was performed with the Helicon Focus 6.2.2 software. Forewing pictures were taken with a Canon camera (Power Shot SX 210 IS) directly from the microscope.

The type specimens of the newly described species are deposited in UB, Universitat de Barcelona, Catalonia (Juli Pujade-Villar col.).

\section{RESULTS AND DISCUSSION Andricus partali n. sp. (Figs, 1-5, 6a) \\ http://zoobank.org/EAE62BA5-FB1C-49EF-AAD7- B326AE37CFDC}

Etymology. Named after the journalist Vicent Partal i Montesinos, for his magnificent speech gloss about the repressed Catalan people on September 9, 2021 (see acknowledgments).

Type material. HOLOTYPE female deposited in UB (col. JP-V) with the following labels: 'Costa Rica, CartagoSan José, Cerro de la Muerte, 3000 m., Villa Mills., 8.iv.1989, col. Hanson' (white label); 'Quercus costaricen., leaf gall with free-rolling cell' (white label); 'Holotype of Andricus partali n. sp. + , desig. JP-V 2021' (red label). PARATYPES ( 10 and $3 q$ deposited in UB): 19 with same data of holotype; $1 q$ idem 26.iii.1995, P. Hanson; $1 \delta^{\lambda}$ and 1 + idem vi.1997, P. Hanson ('Villa Mills.' is not mentioned).

Diagnosis. This species belongs to a sexual form (see comments below). The new species is characterized and differs from other Andricus species by having the following combination of characters: head not broadened behind eye, lower face shining with alutaceous sculpture, malar space without radiating striae, antenna with 12-flagellomeres, F1 long (around 1.4x as long as F2), mesoscutum weakly sculptured, notauli complete, mesopleuron sculptured (weakly on the speculum), tarsal claws simple, lateral propodeal carinae strong and curved outwards in posterior
$1 / 3$, and ventral spine of hypopygium 3.0x as long as broad. The only other Andricus species known from Costa Rica, A. costaricensis, also has a malar space without radiating striae, notauli complete, simple tarsal claws and similar propodeal carinae, but differs from the new species by: head broadened behind eye, lower face with coriaceous sculpture, antenna with 13-flagellomeres, F1 slightly longer than F2, mesoscutum coriaceous, speculum smooth and ventral spine of hypopygium 5.0x as long as broad. The position of $A$. partali n. sp. discussed also in Comments.

Description: Sexual female.

Body length 2.1-2.4 mm ( $\mathrm{n}=4)$.

Color. Light brown to chestnut; head in frontal view and legs amber to yellowish, antenna brown, with first segments (scapus to F2) lighter; lateral scutellum lighter; forewings hyaline with brown veins.

Head. Alutaceous with few white setae on lower face, 2.1 times as broad as long from above, 1.4 times as broad as high and as broad as mesosoma in front view. Gena delicately coriaceous, not broadened behind eye; malar space delicately coriaceous, without striae or malar sulcus, 0.5 times as long as height of eye. POL nearly 1.2 times or slightly longer than OOL; OOL 3.0 times as long as length of lateral ocellus and 1.3 times as long as LOL. Transfacial distance 1.4 times as broad as height of eye; diameter of antennal torulus 1.5 times as large as distance between them, distance between torulus and inner margin of eye equal to the diameter of torulus; lower face shiny, with very delicate alutaceous sculpture, with sparse white setae. Clypeus rectangular, delicately coriaceous, with very small elevated central area, ventrally smooth, widely emarginated, with a short median incision; anterior tentorial pits distinct; epistomal sulcus and clypeo-pleurostomal line distinct but superficial. Frons alutaceous, without setae. Vertex, interocellar area and occiput delicately coriaceous.

Antenna. 14-segmented; slightly longer than mesosoma; scapus compressed and short, 1.6 times as long as pedicel; pedicel globular, 1.5 times as long as broad; F1 1.4 times as long as F2, 2.6 times as long as pedicel; F2 longer than F3; F3=F4; F5-F7 becoming shorter, F8-F11 shorter than F5-F7, all equal in length; F12 1.4x as long as F11; placodeal sensilla present on F2-F13, absent on F1, obscured by setae.

Mesosoma. Slightly longer than high in lateral view; with very sparse white setae. Pronotum alutaceous, with numerous strigae laterally, emarginated along the ventrolateral edge, with short white setae; anterior rim of pronotum narrow; propleuron alutaceous, shining, with smooth area basally. Mesoscutum delicately alutaceous, almost smooth in the center, more strongly impressed outside the notauli; only slightly longer than broad in dorsal view (largest width measured across mesoscutum at the level of the base of tegulae). Notauli complete, deep and narrow, distinctly impressed, slightly converging and not broadened at the posterior end; anterior parallel lines, parapsidal lines and median mesoscutal line absent. Mesoscutellum 0.5 times as 
long as mesoscutum, uniformly coriaceous-rugose laterally, weakly sculptured in central part of disk, with parallel sides and short white setae, elongated in dorsal view, slightly longer than broad, overhanging metanotum; mesoscutellar foveae present, shining, subquadrangular with distinctly elevated coriaceous median carina not delimited basally. Mesopleuron alutaceous, more delicately in the speculum which is sometimes almost smooth, sometimes with very weak transverse carinae, basally smooth, glabrous or with very few white setae; dorsal axillar area alutaceous; lateral axillar area coriaceous and glabrous; axillula short, triangular, alutaceous, with few white setae; subaxillular bar smooth, shining, slightly shorter than height of metanotal trough; postalar process short, inconspicuous; metapleural sulcus reaching mesopleuron in the upper half of its height. Metascutellum, uniformly coriaceous, metanotal trough smooth to weakly alutaceous, with few short white setae; ventral impressed area at least twice as narrow as height of metascutellum, smooth, with distinct longitudinal striae; central propodeal area smooth, shiny, lateral propodeal carinae strong, high, curved outwards in posterior $1 / 3$, glabrous; lateral propodeal area with few long white setae next to propodeal carinae. Nucha with irregular wrinkles and rugae.

Legs. Tarsal claws simple, without basal lobe.

Wings. Forewing longer than body, hyaline, with short dense cilia on margin, radial cell 4.2 times as long as broad; R1 reaching wing margin, Rs nearly straight, nearly reaching wing margin and broadened distally; areolet large, triangular, closed and distinct. $\mathrm{M}$ reaching basalis at half its height.

Metasoma. Shorter than head +mesosoma, as high as long in lateral view; only 2 nd and 7 th metasomal tergites with a few short white setae, only laterally, all other tergites without setae, smooth, shining; 2nd metasomal tergite occupying half the metasomal length in dorsal view. Ventral spine of hypopygium slender, prominent part 3.0 times as long as broad, with sparse, long white setae, not extending beyond the apex of spine.

Male. Similar to female except: head as long as broad in frontal view; malar space shorter, around 0.3 times as long as height of eye; POL 2.0x OOL; OOL slightly shorter than length of lateral ocellus and subequal in length to LOL. Transfacial distance slightly shorter than height of eye; antenna 15-segmented; longer than body length; scapus shorter, 1.3 times as long as pedicel; F1 1.3 times as long as $\mathrm{F} 2$, very slightly curved but broadened distally; F2 $=\mathrm{F} 3$ and slightly longer than F4; F5 $=\mathrm{F} 7$ and slightly longer than F8; F8=F12; F13 slightly shorter than F12; placodeal sensilla present on all segments; sculpture of mesoscutum more impressed and mesopleura smooth. Length: $2.0 \mathrm{~mm}(\mathrm{n}=1)$.

Gall (Fig. 6a). Globular swelling of the leaf blade projecting on both the upper and lower surface of the leaf, located adjacent to the main vein or a secondary vein. Usually there are only one or two galls on a single leaf, rarely more. The gall is up to $10 \mathrm{~mm}$ in diameter, green in color, sometimes with a slightly reddish tinge on the surface. The external wall is coriaceous, quite hard, and with a shiny surface. Mature galls are hollow inside and within the internal air space is a single $2-3 \mathrm{~mm}$ diameter, brown sphere containing the larval chamber, which can become detached and capable of rolling around inside the hollow interior of the gall.

Biology. This new species was found inducing galls on Quercus costaricensis Liebm. (Section Lobatae of Quercus, red oaks), which occurs from $2300 \mathrm{~m}$ to $3600 \mathrm{~m}$ elevation in Costa Rica and western Panama (Morales 2010). The gall appears to belong to the sexual generation. Mature galls were collected in March-April, and adults emerged soon after the galls were collected. Other hymenopterans that emerged from these galls include parasitoids, Quercastichus sp. (Eulophidae) and Torymus sp. (Torymidae).

Distribution. Only known from high elevations in Costa Rica (Cordillera de Talamanca).

Comments. Andricus is a problematic genus that has been repeatedly recovered as non-monophyletic in previous phylogenetic studies (Liljeblad et al. 2008; Stone et al. 2009; Nicholls et al. 2017), and thus needs a thorough taxonomic revision. Some of the characters of the new species described here are not concordant with the morphology of most Andricus species: tarsal claws simple, malar space without radiating striae from clypeus and lower face almost smooth.

The presence or absence of a basal lobe on the tarsal claws is not considered a diagnostic generic character (Melika and Abrahamson 2002). Two large oak gall wasp genera, Callirhytis and Andricus, include species without and with a basal lobe on the tarsal claws, respectively (Weld 1952; Melika 2006). Many species placed by Weld (1952) in Callirhytis (as a genus without a basal lobe on the tarsal claws), in fact, belong to Andricus and vice versa (Melika et al. 2009). Also, some Andricus species in the Western Palaearctic and Neotropical regions do not have radiating striae from clypeus (Melika 2006; Melika et al. 2009), and a few species of Andricus have a smooth lower face (Tang et al. 2012; for example). Thus, the new species fits into the current definition of the genus Andricus, despite the peculiarity of some morphological characters. Further studies and revisions of this genus are needed to clarify the diagnostic characters and true limits of Andricus.

Cameron (1883: 71) described Cynips guatemalensis based exclusively on gall samples, however the drawings of the galls in the same study (Cameron 1883: Table 4, Figs 7 \& 7a) were morphologically discordant from his description in the text. Furthermore, Synergus dorsalis Cameron was described in the same study (Cameron, 1883: 72); the type material of which (adult) was examined by Richie \& Shorthouse (1987: 240) who concluded that it corresponds to an Andricus. Cameron mentions that $S$. dorsalis was obtained from the gall of Cynips guatemalensis, therefore S. dorsalis, currently Andricus dorsalis (Cameron), would be the inducer of the gall of C. guatemalensis (currently 
Andricus guatemalensis). The gall of Andricus partali n. sp. may be similar to the description of Andricus guatemalensis (Cameron). Ritchie \& Shorthouse (1987: 240) also studied the type material of A. guatemalensis (gall), labelled by Cameron, and the authors compared it with "Andricus? mexicana Bassett", a velvety leaf gall; then, they confirmed that A. guatemalensis (gall) corresponds to Cameron's drawing (Fig. 6b), a velvety leaf gall. Thus, the description of A. guatemalensis (gall) is erroneous. According to the $\mathrm{ZNC}$, a drawing cannot be a type (nor a description); a 'Type' should be a sample, or a synthetic series of samples (Brothers pers. com.). Thus, the type series of A. guatemalensis (gall) and of Andricus dorsalis (adult) deposited in the British Museum are the true syntypes of both species, and not the description by Cameron. Pujade-Villar et al. (2011) considered Andricus mexicanus Bassett and Cynips guatemalensis Cameron as incertae sedis, since they were described based only on the velvety leaf galls, which are impossible to differentiate from other velvety leaf galls on leaves that are known. Based on the conclusions of Ritchie \& Shorhouse (1987) we know the inducer of the gall Andricus dorsalis (Cameron) and after having the opportunity to examine the type of this species we conclude that it belongs to the tecturnarum group (JP-V unpublished data). Therefore, $A$. guatemnalensis is a species morphologically distinct (both the gall and the adult) from the new species described here, and Andricus partali n. sp. is a valid species distinct from A. guatemalensis ( $=$ S. dorsalis). As was mentioned, neither a description nor a drawing are "valid" for anything beyond providing information about which the author considered relevant, and either (or both) could be erroneous in several aspects. In summary, even though the description of the gall by Cameron is similar to that described here and given that the verbal descriptions do not correspond to the drawings, the only way to determine the correct application of names is to examine the type specimens. By this means it can be decided whether the descriptions or the drawings are more precise. For these reasons, Cynips guatemalensis, considered in this study as dubida species, corresponds to a multilocular velvety gall on the leaves (Fig. 6b-c) very distinct from the leaf gall described here (A. parlati, Fig. 6a). The lectotype of Cynips guatemalensis is designed here (Fig. 6c). Cameron (1883: 70) described also another velvety gall, Cynips imitator, from Guatemala in the same place, nevertheless this species occurs in twigs (Cameron, 1883: Fig. 8).

\section{ACKNOWLEDGMENTS}

We thank the anonymous revisors for their comments and contributions that have substantially improved the original manuscript. We also thank Denis J. Brothers (School of Life Sicences, University of KwaZulu-Natal, South Africa) for the taxonomic remarks regarding the species Cynips guatemalensis. We also thank Joseph Monks (curator of the Hymenopteran collection of the British Museum) for sending providing the pictures of $C$. guatemalensis type material and for all the effort made to find the syntypes. Lastly, to the person that this new species I dedicated, Vicent Partal i Montesinos, for his reflections that can be listen in https:// www.vilaweb.cat/noticies/ens-heu-decebut-medall-honorvicent-partal-parlament-video/.

\section{LITERATURE CITED}

Cameron, P. 1883. Zoology. Insecta. Hymenoptera. Biologia Centrali-Americana. Vol. 1. 497 pp. +120 pl.

Cuesta-Porta, V., Arnedo, M.A., Cibrián-Tovar, D., BarreraRuiz, U.M., García-Martiñón, R.D., Equihua-Martínez, A., Estrada-Venegas, E.G., Clark-Tapia, R., RomeroRangel, S. and J. Pujade-Villar. 2020. A new genus of oak gall wasp, Striatoandricus Pujade-Villar (Hymenoptera: Cynipidae: Cynipini) from America with descriptions of two new Mexican species. Zoological Studies, 59: e8. http://doi.org/10.6620/ZS.2020.59-08.

Fernández-Garzón, S., Rodríguez, P.A., Roca-Cusachs, M. and J. Pujade-Villar. 2017. First record of Zapatella grahami Pujade-Villar and Melika 2012 (Hymenoptera: Cynipidae) in Colombia (South America). Arquivos Entomolóxicos, 18: 71-74.

Harris, R. 1979. A glossary of surface sculpturing. State of California, Department of Food and Agriculture, Occasional Papers in Entomology, 28: 1-31.

Liljeblad, J. and F. Ronquist. 1998. A phylogenetic analysis of higher-level gall wasp relationship (Hymenoptera: Cynipidae). Systematic Entomology, 23: 229-252. http://doi.org/10.1046/j.1365-3113.1998.00053.x

Liljeblad, J., Ronquist, F., Nieves-Aldrey, J.L., Fontal-Cazalla, F., Ros-Farre, P., Gaitros, D. and J. Pujade-Villar. 2008. A Fully Web-Illustrated Morphological Phylogenetic Study of Relationships among Oak Gall Wasps and Their Closest Relatives (Hymenoptera: Cynipidae). Zootaxa, 1796(1): 1-73. https://doi.org/10.11646/zootaxa.1796.1.1

Medianero, E. and J.L. Nieves-Aldrey. 2010. The Genus Amphibolips Reinhard (Hymenoptera: Cynipidae: Cynipini) in the Neotropics, with Description of three new Species from Panama. Zootaxa, 2360: 47-62. https://doi.org/10.11646/zootaxa.2360.1.3

Medianero, E. and J.L. Nieves-Aldrey. 2011a. Primer estudio de las avispas de las agallas de la República de Panamá, incluyendo una lista actualizada de los cinípidos neotropicales (Hymenoptera, Cynipidae). Boletín de la S.E.A., 48: 89-104.

Medianero, E. and J.L. Nieves-Aldrey. 2011b. First record of the genus Disholcaspis Dalla Torre and Kieffer (Hymenoptera: Cynipidae: Cynipini) in the Neotropics, with description of two new species from Panama. Zootaxa, 2802: 23-33. https://doi.org/10.11646/ zootaxa.2802.1.2

Medianero, E. and J.L. Nieves-Aldrey. 2013. Barucynips panamensis, a new genus and species of oak gall wasps (Hymenoptera: Cynipidae: Cynipini) from Panama, 
and description of a new species of Coffeikokkos. Zookeys, 277: 25-46. http://dx.doi.org/10.3897/ zookeys.277.3942

Medianero, E. and J.L. Nieves-Aldrey. 2014 Callirhytis cameroni: a new species of oak gall wasp (Hymenoptera: Cynipidae: Cynipini) from Panama. Florida Entomologist, 97(4): 1710-1717. http://dx.doi.org/10.1653/024.097.0446

Medianero, E. and J.L. Nieves-Aldrey. 2017. First record of the oak gall wasp genus Neuroterus Hartig, 1840 (Hymenoptera, Cynipidae, Cynipini) from Central America with description of three new species from Panama and Costa Rica. Graellsia, 73(1): e057. http:// dx.doi.org/10.3989/graellsia.2017.v73.178

Medianero, E., Nieves-Aldrey, J. L. and G. Melika. 2011a. Two new Neotropical species of oak gall wasps of the genus Loxaulus Mayr (Hymenoptera: Cynipidae: Cynipini) from Panama. Zootaxa, 2811: 37-46. https://doi.org/10.11646/zootaxa.2811.1.3

Medianero, E., Nieves-Aldrey, J. L. and J. PujadeVillar. 2011b. The genus Odontocynips Kieffer, 1910 (Hymenoptera, Cynipidae, Cynipini) in Panama, with redescription of Cynips championi Cameron 1883. Graellsia, 67(1): 35-46. https://doi.org/10.3989/ graellsia.2011.v67.033

Melika, G. 2006. Gall Wasps of Ukraine. Cynipidae. Vestnik zoologii, supplement 21(1-2): 1-300, 301-644.

Melika, G. and W.G. Abrahamson. 2002. Review of the world genera of oak cynipid wasps (Hymenoptera: Cynipidae, Cynipini) (pp. 150-190). In: Melika, G. and Cs. Thuróczy (Eds.) Parasitic Wasps: Evolution, Systematics, Biodiversity and Biological Control. Agroinform, Budapest.

Melika, G., Hanson, P. and J. Pujade-Villar. 2011. A new species of Disholcaspis Dalla Torre and Kieffer oak gallwasp from Costa Rica (Hymenoptera: Cynipidae: Cynipini). Dugesiana, 18(1): 17-22. https://doi.org/10.32870/dugesiana.v18i1.3985

Melika, G., Pérez Hidalgo, N., Hanson, P. and J. Pujade-Villar. 2009. New species of oak gallwasp from Costa Rica (Hymenoptera: Cynipidae: Cynipini). Dugesiana, 16(1): 35-39. https://doi.org/10.32870/dugesiana.v16i1.3924

Morales, J. F. 2010. Fagaceae (pp. 776-781). In: B. E. Hammel, M. H. Grayum, C. Herrera and N. Zamora (Eds.). Manual de Plantas de Costa Rica, Vol. V. Dicotiledóneas (Clusiaceae - Gunneraceae). Monographs in Systematic Botany from the Missouri Botanical Garden, 119.

Nicholls, J. A., Melika, G. and G.N. Stone. 2017. Sweet Tetra-Trophic Interactions: Multiple Evolution of Nectar Secretion, a Defensive Extended Phenotype in Cynipid Gall Wasps. The American Naturalist, 189(1): 67-77. https://doi.org/10.1086/689399

Nicholls, J.A. and J. Pujade-Villar. 2020. Re-instatement of the species name Callirhytis erythrosoma (Dettmer,
1933), with comments on other Callirhytis species (Hymenoptera: Cynipidae). Butlletí de la Institució Catalana d'Història Natural, 84: 31-34.

http://dx.doi.org/10.2436/20.1502.01.35

Nieves-Aldrey, J.L. and E. Medianero. 2010. Description of the first Neotropical species of Bassettia Ashmead, 1887 (Hymenoptera, Cynipidae, Cynipini) from Panama. Graellsia, 66(2): 213-220.

http://dx.doi.org/10.3989/graellsia.2010.v66.029

Nieves-Aldrey, J.L., Nicholls, J.A., Tang CH.-T., Melika, G., Stone G.N. Pujade-Villar, J., Buffington, M., Maldonado, Y. and E. Medanero. 2021. Re-description and systematic re-appraisal of the genus Kokkocynips Pujade-Villar and Melika, (Hymenoptera: Cynipidae: Cynipini), including new combinations of Nearctic species and the description of a new species from Panama. Zootaxa 4938 (2): 205-232.

https://doi.org/10.11646/zootaxa.4938.2.3

Pénzes, Z., Tang, C.T., Stone, G.N., Nicholls, J.A., Schwéger, S., Bozsó, M. and G. Melika. 2018. Current status of the oak gallwasp (Hymenoptera: Cynipidae: Cynipini) fauna of the Eastern Palaearctic and Oriental Regions. Zootaxa, 4433 (2): 245-289. https://dx.doi. org/10.11646/zootaxa.4433.2.2

Pujade-Villar, J. 2008. Description of Odontocynips hansoni n. sp., from Costa Rica (Hymenoptera. Cynipi dae). Dugesiana, 15: 79-85.

Pujade-Villar, J., Caicedo-Ramírez, G., Rodríguez, P. A., Fernández-Garzón, S. and M. Roca Causachs. 2017. Primer reporte de una especie de cinípido dañina para Q. humboldtii en Colombia: Zapatella petiolata n. sp. Pujade-Villar and Caicedo (Hym., Cynipidae). Butlleti de la Institució Catalana d'Història Natural, 81:37-46.

Pujade-Villar, J., Hanson, P. and G. Melika. 2012a. A new genus of oak gallwasp, Coffeikokkos Pujade-Villar and Melika, gen. n., with a description of a new species from Costa Rica (Hymenoptera, Cynipidae). ZooKeys, 168: 19-29. https://doi.org/10.3897/zookeys.168.2030

Pujade-Villar, J. and P. Hanson. 2021. Neuroterus titou n. sp. from Costa Rica (Cynipidae: Cynipini). Butlletí de la Institució Catalana d'Història Natural, 85 (3): 139145.

Pujade-Villar, J., Hanson, P., Medina, C. A., Torres, M. and G. Melika. 2012b. A new genus of oak gallwasps, Zapatella Pujade-Villar and Melika, gen. n., with a description of two new species from the Neotropics (Hymenoptera, Cynipidae, Cynipini). ZooKeys, 210: 75-104. https://doi.org/10.3897/zookeys.210.3014

Pujade-Villar, J. and P.A. Rodríguez. 2015. Primera cita del género Melikaiella (Hym. Cinipidae) para Colombia y descripción de una nueva especie. Orsis, 29: 193-404.

Pujade-Villar, J. and Rodríguez, P. A. and G. Caicedo. 2015. Dos nuevas especies de Zapatella (Hym., Cynipidae) para Colombia que producen agallas en ramas de Quercus humboldtii (Fagaceae). Butlletí de la Institució Catalana d'Història Natural, 79: 79-90. 
Ritchie, A.J. \& Shorthouse, J.D. 1987. A review of the species of Synergus from Guatemala, with notes on Cynips guatemalensis Cameron (Hymenoptera: Cynipidae). Proceedings of the Entomological Society of Washington, 89 (2): 230-241.

Ronquist, F. and G. Nordlander. 1989. Skeletal morphology of an archaic cynipoid, Ibalia rufipes (Hymenoptera: Ibaliidae). Entomologica Scandinavica, supplement 33: $1-60$.

Stone, G. N., Hernandez-Lopez, A., Nicholls, J. A., Di Pierro, E., Pujade-Villar, J., Melika, G. and J.M. Cook. 2009. Extreme Host Plant Conservatism during at Least 20 Million Years of Host Plant Pursuit by Oak Gallwasps. Evolution: International

Recibido: 13 de octubre 2021

Aceptado: 25 de octubre 2021
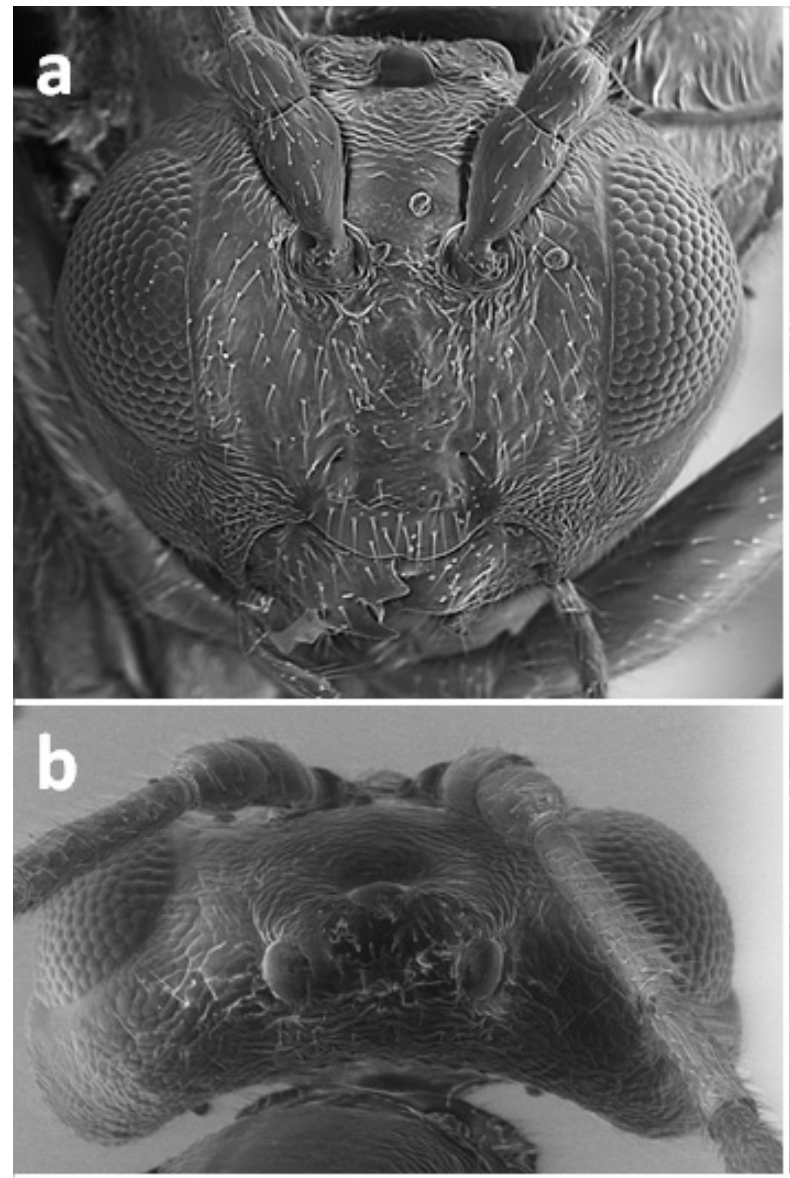

Journal of Organic Evolution, 63(4): 854-69. https://doi.org/10.1111/j.1558-5646.2008.00604.x

Stone, G.N., Schönrogge, K., Atkinson, R.J., Bellido, D. and J. Pujade-Villar. 2002. The population biology of oak gall wasps (Hymenoptera: Cynipidae). Annual Review of Entomology, 47: 633-668. https://doi.org/10.1146/annurev.ento.47.091201.145247 Tang, C.-T., Sinclair, F., Yang, M.-M. and G. Melika. 2012. A new Andricus Hartig oak gallwasp species from China (Hymenoptera: Cynipidae: Cynipini). Journal of Asian-Pacific Entomology, 15: 601-605.

https://doi.org/10.1016/j.aspen.2012.07.005

Weld, L.H. 1952. Cynipoidea (Hym.) 1905-1950 being a Supplement to the Dalla Torre and Kieffer monograph the Cynipidae in Das Tierreich, Leiferung 24, 1910 and bringing the systematic literature of the world up to date, including keys to families and subfamilies and list of new generic, specific and variety names. Ann Arbor, Michigan, Privately Printed.
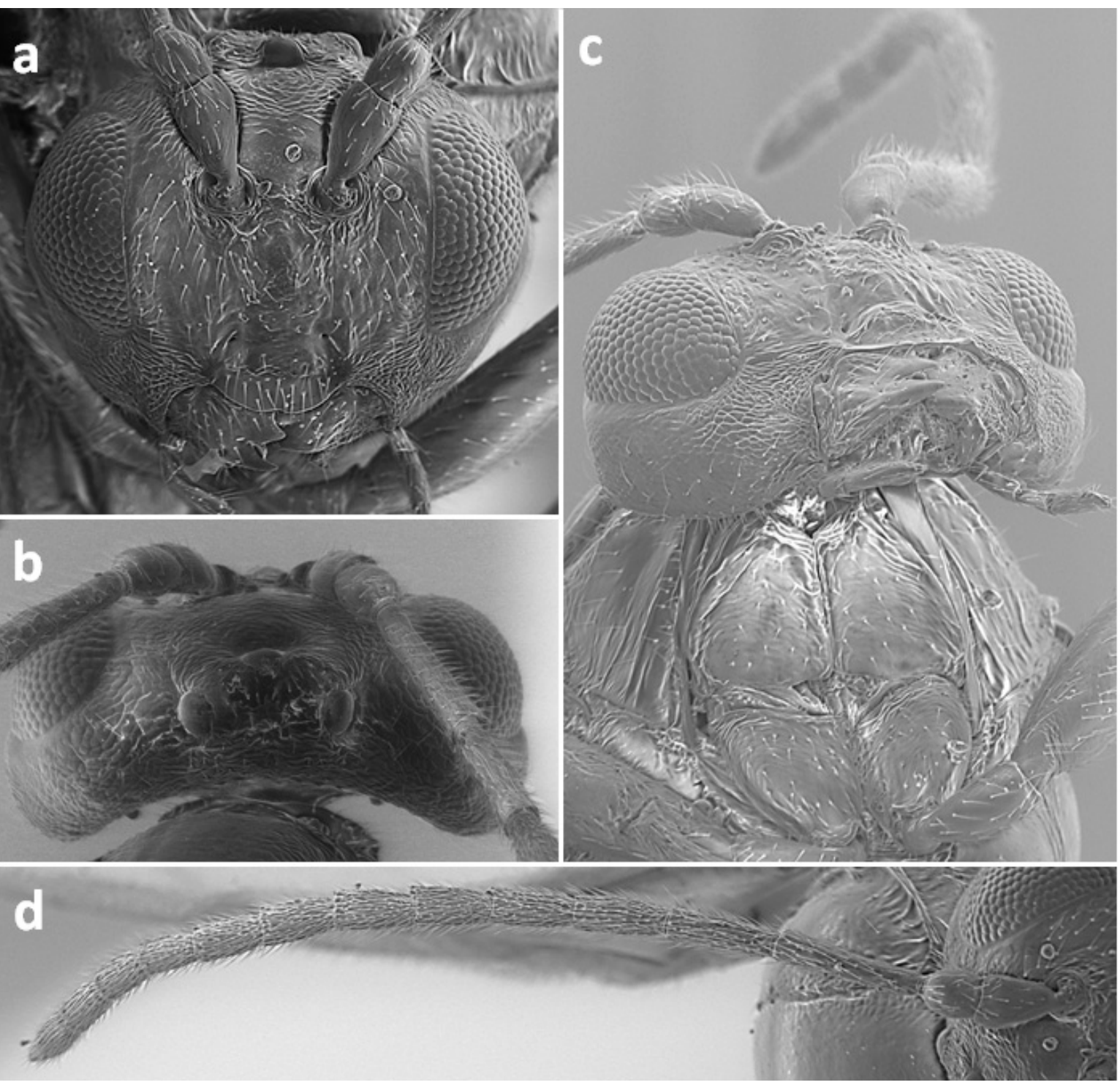

Figure 1. Andricus partali n. sp. : : (a) head in frontal view, (b) head in dorsal view, (c) head in ventral view and propleura, (d) antenna. 


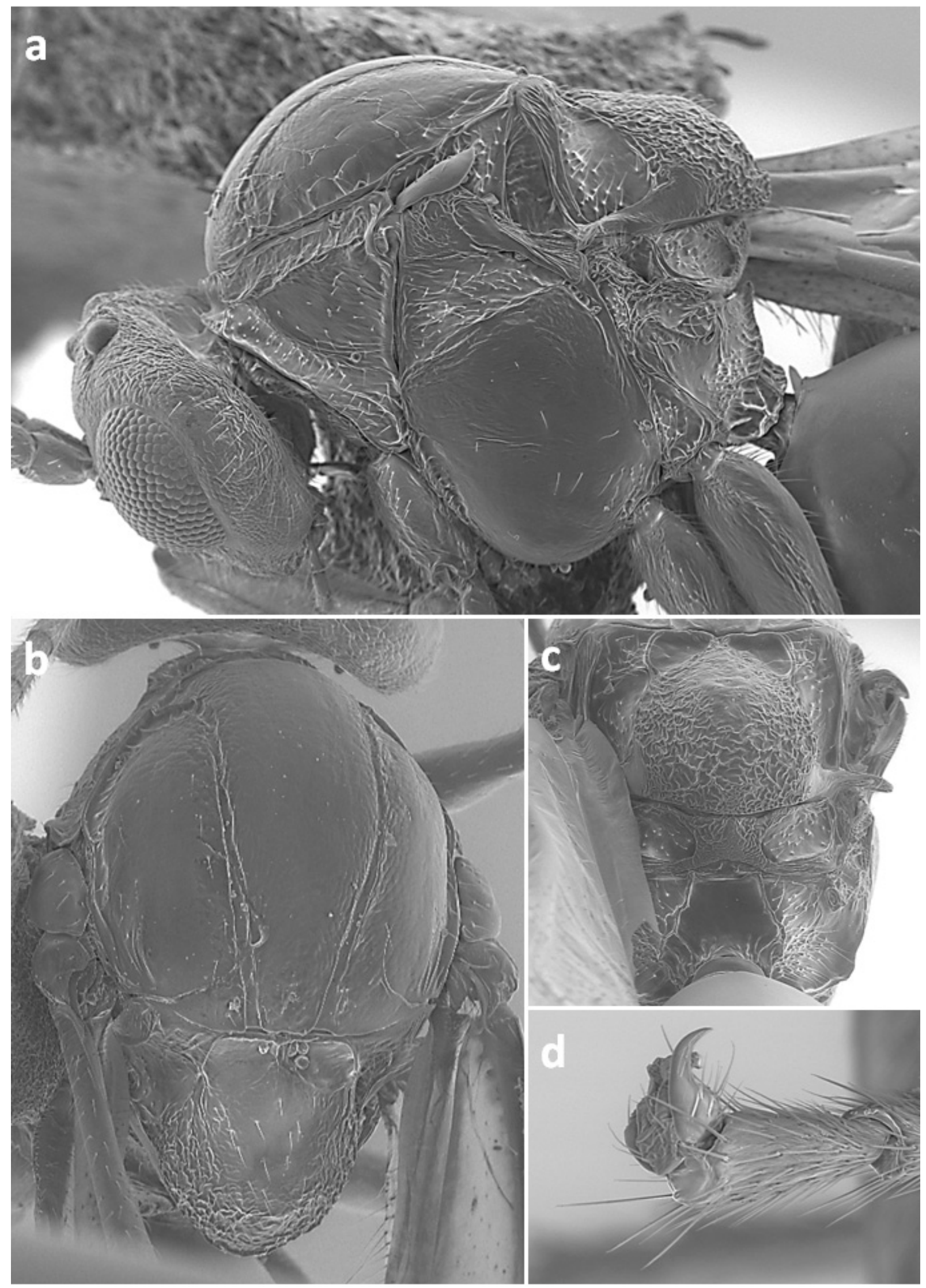

Figure 2. Andricus partali n. sp. + : (a) mesosoma in lateral view, (b) mesonotum in dorsal view, (c) mesosoma in posterior view, (d) tarsal claws. 


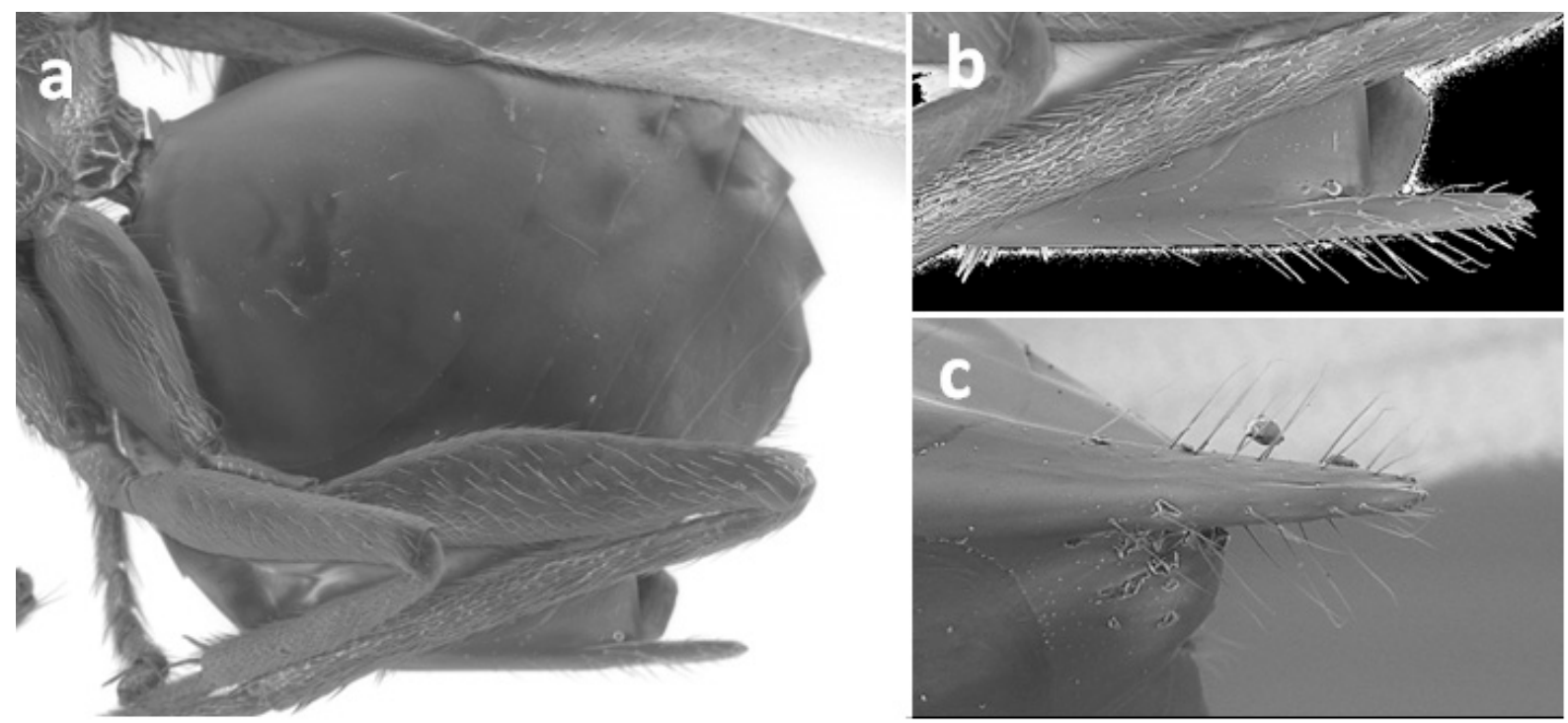

Figure 3. Andricus partali n. sp. ㅇ: (a) metasoma in lateral view, (b) ventral spine of hypopygium in lateral view, (c) ventral spine in ventral view.

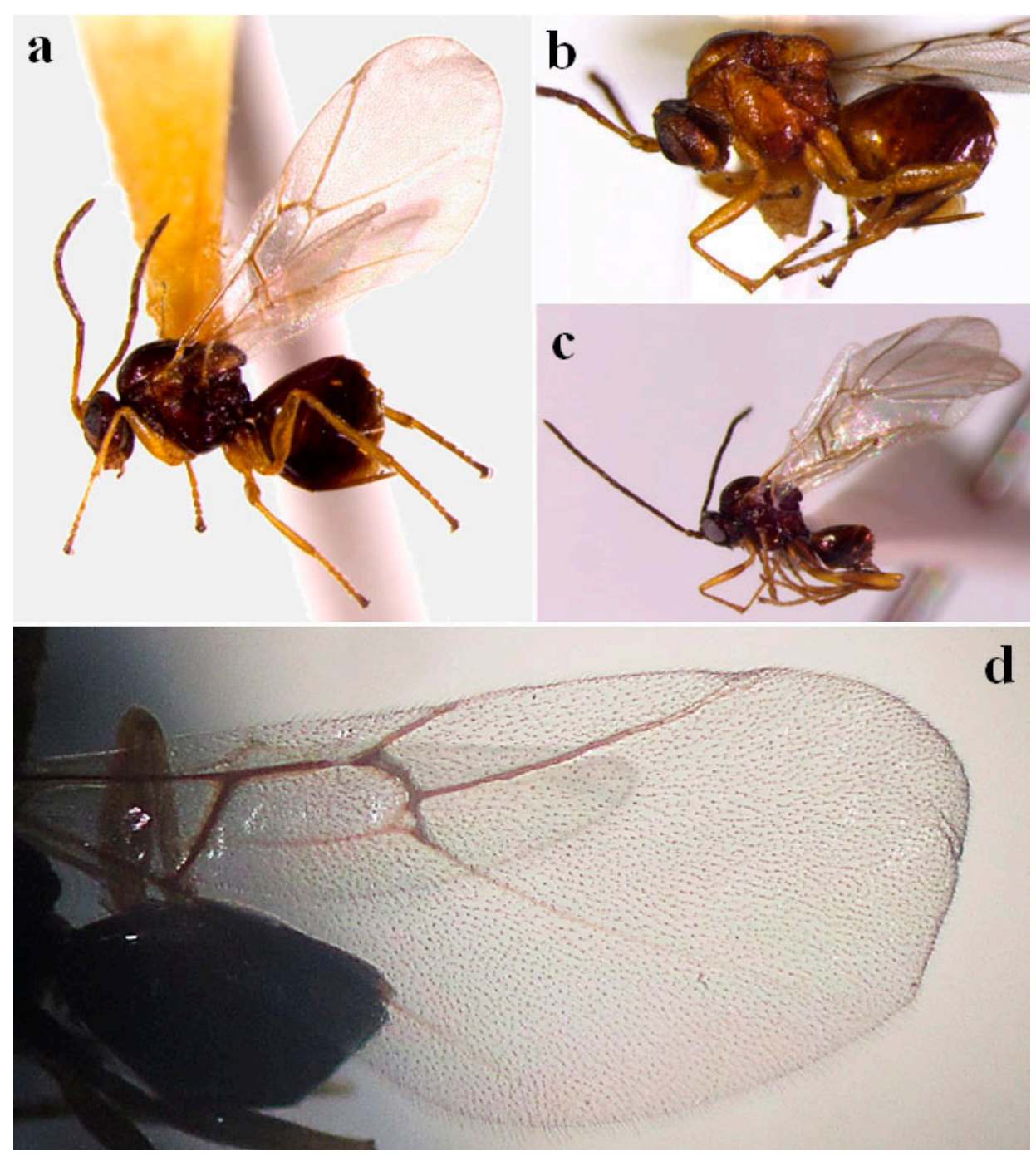

Figure 4. Andricus partali n. sp.: (a-b) habitus female, (c) habitus male, (d) forewing. 


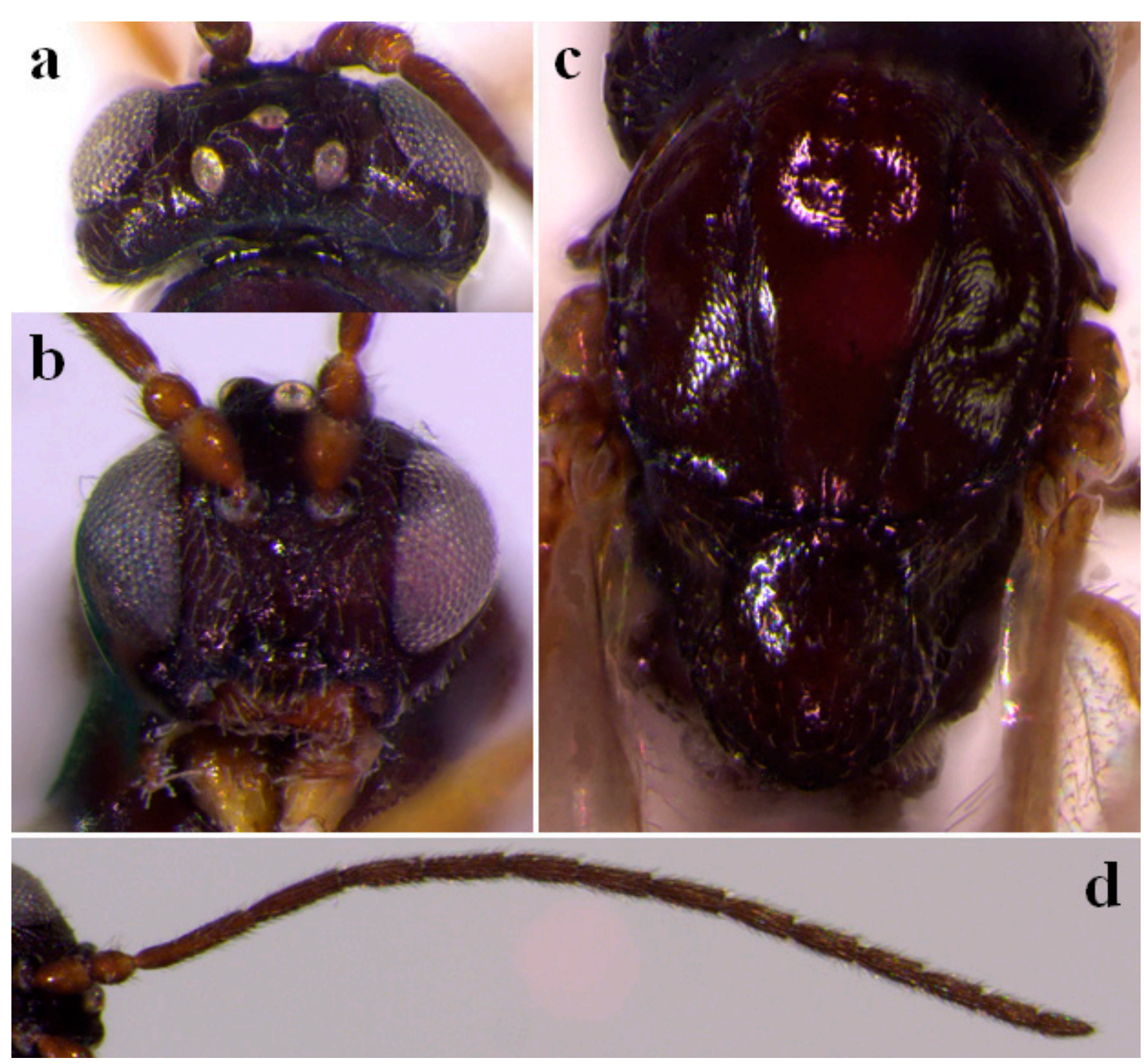

Figure 5. Andricus partali n. sp. $\overbrace{}^{\Uparrow}$ : (a) head in dorsal view, (b) head in frontal view, (c) mesosoma in dorsal view, (d) antenna. 


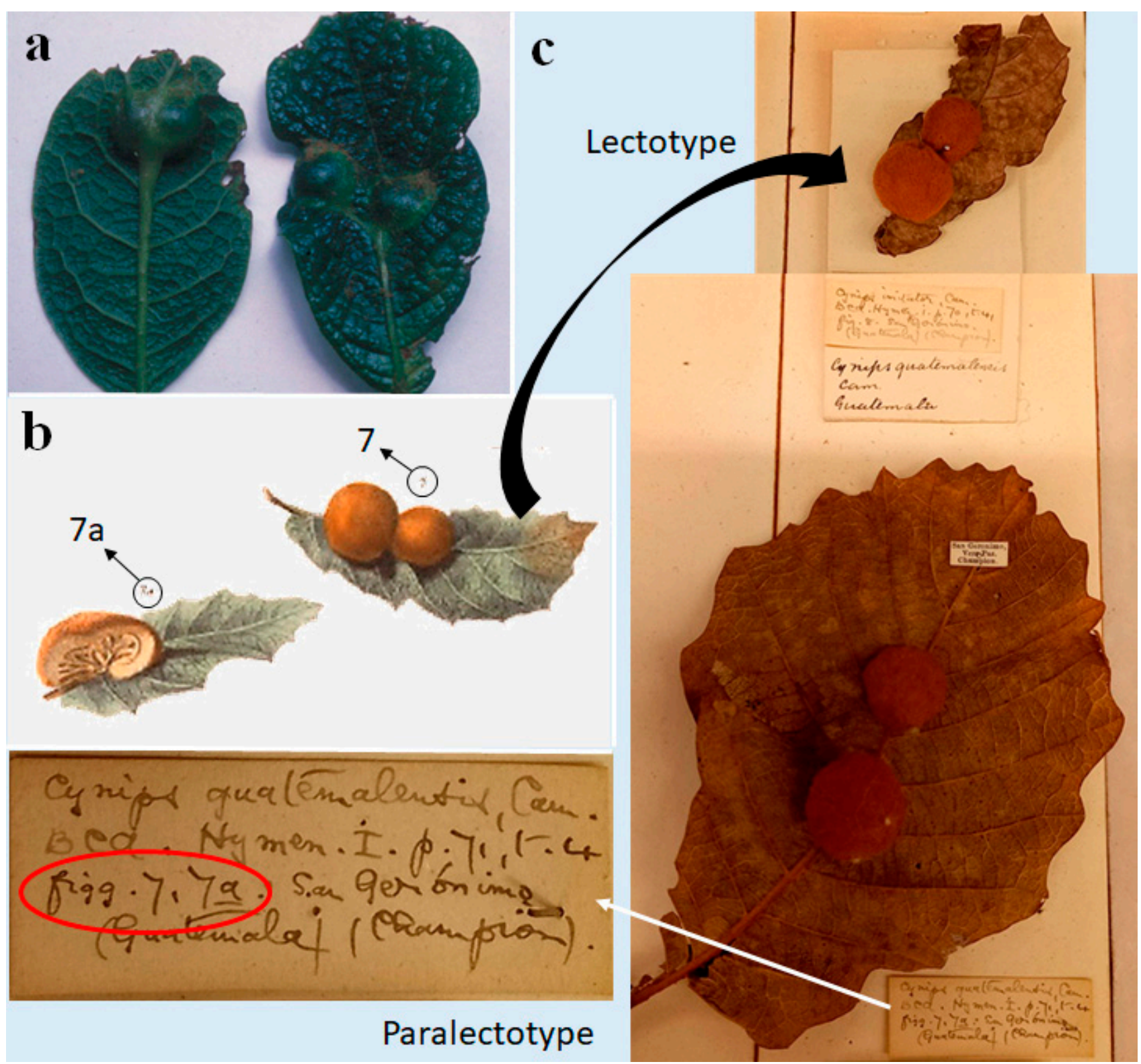

Figure 6. (a) Gall of Andricus partali n. sp. on Q. costaricensis. (b) Drawing in Cameron (1883) illustrating Cynips guatemalensis gall. (c) Syntypes of $C$. guatemalensis including the designation of lectotype. 